\title{
PENGARUH PANDEMI COVID-19 TERHADAP KINERJA DAN KONDISI KEUANGAN PERUSAHAAN PUBLIK SEKTOR PROPERTI
}

\author{
Richard Lowardi dan Maswar Abdi \\ Program Studi Manajemen Fakultas Ekonomi Universitas Tarumanagara, Jakarta \\ Lowardirichard17@gmail.com
}

\begin{abstract}
Abstrak: Tujuan penelitian ini adalah untuk mengetahui bagaimana pengaruh pandemi covid19 terhadap kinerja dan kondisi keuangan perusahaan publik sektor properti Indonesia. Variabel independen yang diteliti adalah pandemi covid-19. Variabel dependen yang diteliti adalah kinerja dan kondisi keuangan. Metode penelitian yang digunakan adalah membandingkan data keuangan sebelum ada covid-19 dan setelah ada covid-19 (semester I 2020) menggunakan uji Wilcoxon. Penelitian ini mengambil seluruh populasi perusahaan publik sektor properti Indonesia. Populasi sektor properti dibagi menjadi dua yaitu papan utama sebanyak 25 perusahaan dan papan pengembangan sebanyak 17 perusahaan. Hasil penelitian menunjukkan bahwa pandemi covid-19 berpengaruh negatif dan signifikan terhadap kinerja keuangan perusahaan properti papan utama dan papan pengembangan, pandemi covid-19 berpengaruh negatif dan tidak signifikan terhadap likuiditas perusahaan properti papan utama, pandemi covid-19 berpengaruh negatif dan tidak signifikan terhadap solvabilitas perusahaan properti papan utama, pandemi covid-19 berpengaruh negatif dan tidak signifikan terhadap likuiditas perusahaan properti papan pengembangan, pandemi covid-19 berpengaruh positif dan signifikan terhadap solvabilitas perusahaan properti papan pengembangan.
\end{abstract}

Keyword: Covid-19, properti, kondisi keuangan, kinerja keuangan.

Abstract: The purpose of research is to obtain empirical evidence about the effects of covid19 pandemic to financial performance and condition of property public companies. Independent variable used is covid-19 pandemic. Dependent variables used are financial performance and financial condition. The research method is comparing financial data before covid-19 and after covid-19 (semester I 2020) by Wilcoxon test. This research takes the entire population of Indonesia's property public companies. This population divided into two categories which are main boards (25 companies) and development boards (17 companies). The results found are that covid-19 pandemic has negative and significant effects on financial performance of property main boards and development boards, covid-19 pandemic has negative and not significant effects on liquidity of property main boards, covid-19 pandemic has negative and not significant effects on solvability of property main boards, covid-19 pandemic has negative and not significant effects on liquidity of property development boards, covid-19 pandemic has positive and significant effects on solvability of property development boards.

Key Word: Covid-19, Property, Financial performance, Financial condition.

\section{LATAR BELAKANG}

Covid-19 adalah virus baru yang pertama kali ditemukan di Wuhan, China di akhir Desember 2019. Hanya dalam 3 bulan saja, hampir semua negara telah terinfeksi oleh covid19 sehingga virus ini diumumkan WHO sebagai pandemi global. Pada awal Maret 2020, covid19 pertama kali ditemukan di Indonesia. Kebijakan social-distancing diterapkan pemerintah untuk mengurangi penyebaran virus tersebut (Kompas.com). 
Kebijakan tersebut menurunkan sebagian besar sektor bisnis sehingga mengakibatkan penurunan ekonomi dan permintaan (liputan6.com). Penelitian ini akan membahas lebih dalam seberapa besar kinerja dan kondisi keuangan sektor properti dipengaruhi pandemi covid-19. Utami (2017) dalam penelitiannya mengenai dampak krisis ekonomi 2008 terhadap kinerja keuangan sektor properti Indonesia, menemukan bahwa Debt to Equity Ratios dan Return On Equity Ratios mengalami penurunan signifikan setelah krisis ekonomi 2008. Lai et al., (2014) dalam penelitiannya menemukan bahwa sektor konstruksi di Malaysia mengalami penurunan signifikan oleh krisis ekonomi 2008 hanya dalam sisi profitabilitasnya yaitu NPM, ROAE, dan $R O A A$, sedangkan likuiditas dan solvabilitas perusahaan tidak mengalami perubahan signifikan. Hipotesis yang dapat diambil adalah pandemi covid-19 memiliki pengaruh negatif dan signifikan terhadap profitabilitas perusahaan sektor properti, covid-19 memiliki pengaruh negatif dan signifikan terhadap likuiditas perusahaan sektor properti, dan covid-19 memiliki pengaruh positif dan signifikan terhadap solvabilitias perusahaan sektor properti.

Penelitian ini akan meneruskan penelitian - penelitian sebelumnya mengenai dampak menurunnya ekonomi suatu negara terhadap kinerja dan kondisi keuangan suatu sektor bisnis. Penelitian ini akan memberikan informasi bagaimana kondisi dan kinerja keuangan sektor properti dipengaruhi oleh pandemi covid-19 yang menurunkan perekonomian nasional. Informasi mengenai bagaimana kinerja dan kondisi keuangan sektor properti di masa perekonomian tidak baik dapat dimanfaatkan untuk penelitian - penelitian selanjutnya dan untuk para investor yang tertarik berinvestasi di sektor ini.

\section{KAJIAN TEORI}

Dasar teori yang digunakan dalam penelitian ini adalah teori lingkungan perusahaan menurut Daft dan Macic (2009).

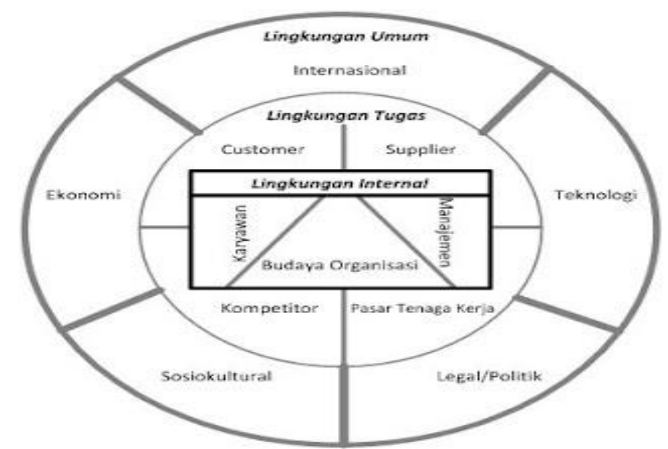

Gambar 2.1 Teori Lingkungan Perusahaan

Daft dan Macic (2009)

Pandemi Covid-19 pada mulanya akan mempengaruhi legal negara yaitu penerbitan kebijakan social-distancing. Hal ini mengganggu aktivitas perekonomian negara sehingga menurunkan daya beli dan permintaan customer sektor properti. Penurunan permintaan akan berdampak terhadap pengurangan pendapatan perusahaan. Pada akhirnya, penurunan permintaan mempengaruhi kinerja dan kondisi keuangan perusahaan sektor properti.

Kinerja keuangan adalah prestasi perusahaan dalam mencapai tujuan utama keuangannya (Buvaneswar. R dan Venkatesh.M, 2013). Tujuan utama keuangan perusahaan adalah memaksimalkan nilai kekayaan pemilik (Gitman, 2003). Alat ukur yang paling tepat untuk menilai hal tersebut adalah Return On Equity (ROE) karena rasio ini secara langsung menggambarkan peningkatan nilai kekayaan pemilik. Penelitian ini menggunakan tiga rasio lain yaitu Return On Assets (ROA), Net Profit Margin (NPM), dan Gross Profit Margin (GPM) untuk menilai tujuan antara kinerja keuangan perusahaan. 
Menurut Kamnikar etal., (2006), kondisi keuangan adalah kemampuan perusahaan dalam membayar kewajibannya dan melanjutkan pengoperasiannya. Penelitian ini akan menggunakan dua rasio keuangan sebagai alat ukurnya yaitu rasio likuiditas dan solvabilitas.. Rasio keuangan dipilih sebagai alat pengukuran dalam penelitian ini karena dapat menggambarkan secara jelas dan sederhana kinerja dan kondisi keuangan perusahaan.

Terdapat beberapa penelitian terdahulu yang membahas mengenai pengaruh penurunan ekonomi terhadap kinerja dan kondisi keuangan perusahaan. Utami (2017) dalam penelitiannya mengenai dampak krisis ekonomi 2008 terhadap kinerja keuangan sektor properti Indonesia, menemukan bahwa Debt to Equity Ratios dan Return On Equity Ratios mengalami penurunan signifikan setelah krisis ekonomi 2008. Sedangkan, Total Assets Turnover, Net Profit Margin, dan Current ratio tidak terdapat perbedaan signifikan.

Chan dan Aziz (2017) dalam penelitiannya yang membahas pengaruh krisis ekonomi 2008 terhadap perusahaan publik sektor properti di Malaysia menemukan bahwa Return On Equity (ROE) dan Return On Assets (ROA) terpengaruh krisis ekonomi. Namun, Net Profit Margin (NPM) tidak terpengaruh signifikan oleh krisis ekonomi 2008. Current ratio dan Quick ratio mengalami penurunan yang tidak signifikan. Total Debts to Total Assets dan Debt to Equity Ratio mengalami peningkatan yang juga tidak signifikan.

Dari semua penelitian terdahulu mengenai topik yang berkaitan, dapat diambil hipotesis mengenai pengaruh covid-19 terhadap kinerja dan kondisi keuangan sektor properti adalah sebagai berikut :

\section{TABEL 2.1}

Kerangka pengukuran dan Hipotesis

\begin{tabular}{|c|c|c|c|c|}
\hline \multicolumn{2}{|r|}{ PRA COVID 19} & \multicolumn{2}{|c|}{ MASA COVID 19} & $\begin{array}{l}\text { Hipotesis Perbedaan dan } \\
\text { Pengukuran }\end{array}$ \\
\hline \multicolumn{2}{|c|}{ Kinerja Keuangan } & \multicolumn{2}{|c|}{ Kinerja keuangan } & \\
\hline 1 & ROE & 1 & ROE & Negatif dan signifikan \\
\hline 2 & ROA & 2 & ROA & Negatif dan signifikan \\
\hline 3 & NPM & 3 & NPM & Negatif dan signifikan \\
\hline 4 & GPM & 4 & GPM & Negatif dan signifikan \\
\hline \multicolumn{2}{|c|}{ Kondisi Keuangan } & \multicolumn{2}{|c|}{ Kondisi Keuangan } & \\
\hline 1 & Current Ratio & 1 & Current Ratio & Negatif dan tidak signifikan \\
\hline 2 & Quick Ratio & 2 & Quick Ratio & Negatif dan tidak signifikan \\
\hline 3 & Cash Ratio & 3 & Cash Ratio & Negatif dan tidak signifikan \\
\hline 4 & DER & 4 & DER & Positif dan tidak signifikan \\
\hline 5 & TDTA & 5 & TDTA & Positif dan tidak signifikan \\
\hline
\end{tabular}

\section{METODOLOGI}

Subjek penelitian ini adalah perusahaan sektor properti Indonesia yang sudah terdaftar di BEI sejak semester I 2017 sampai semester I 2020. Objek penelitian adalah kinerja keuangan dan kondisi keuangan. Kinerja keuangan diukur dari $R O E$. Kondisi keuangan diukur dari rasio solvabilitas dan likuiditas. 
Tabel 3.1 Operasionalisasi Variabel

\begin{tabular}{|c|c|c|c|}
\hline Variabel & Rumus & Variabel & Rumus \\
\hline ROE ( Return On Equity) & Cash Ratio & $\frac{\text { Cash + Marketable Securities (MS) }}{\text { Current Liabilities }}$ \\
\hline NPM (Net Profit Margin) & $\frac{\text { EAT }}{\text { Total Revenue }}$ & Quick Ratio & $\frac{\text { Cash + MS + Account Receivable }}{\text { Current Liabilities }}$ \\
\hline ROA (Return On Asset) & $\frac{\text { EAT }}{\text { Total Assets }}$ & Debt To Equity ratio (DER) & $\frac{\text { Thatal Debts }}{\text { Shareholder Equity }}$ \\
\hline GPM (Gross Profit Margin) & $\frac{\text { Gross Profit }}{\text { Total Revenue }}$ & $\begin{array}{c}\text { Total Debt to Total Assets } \\
\text { (TDTA) }\end{array}$ \\
\hline Current Ratio & $\frac{\text { Current Assets }}{\text { Current Liabilities }}$ & &
\end{tabular}

Penelitian ini tidak menggunakan teknik sampling karena mengambil keseluruhan populasi sektor properti. Jumlah populasi yang dapat diambil adalah 23 perusahaan papan utama dan 12 perusahaan papan pengembangan. Uji statistik yang digunakan dalam penelitian ini adalah uji deskriptif , uji normalitas sebagai syarat uji paired t-test, uji paired t-test, dan uji Wilcoxon jika data tidak normal setelah diuji normalitas.

\section{HASIL ANALISIS DATA}

Banyaknya data yang tidak normal mengharuskan penelitian ini untuk menggunakan uji selain paired $t$ - test yaitu uji Wilcoxon.

\begin{tabular}{|c|c|c|c|c|c|c|c|c|c|}
\hline & $\begin{array}{l}\text { PRA_ROA- } \\
\text { MASA_ROA }\end{array}$ & $\begin{array}{l}\text { PRA_NPM- } \\
\text { MASA_NPM }\end{array}$ & $\begin{array}{l}\text { PRA_GPM- } \\
\text { MASA_GPM }\end{array}$ & $\begin{array}{l}\text { PRA_ROE- } \\
\text { MASA_ROE }\end{array}$ & $\begin{array}{c}\text { PRA_CURRE } \\
\text { NT- } \\
\text { MASA_CURR } \\
\text { ENT }\end{array}$ & $\begin{array}{l}\text { PRA_CASH- } \\
\text { MASA_CASH }\end{array}$ & $\begin{array}{l}\text { PRA_QUICK- } \\
\text { MASA_QUICK }\end{array}$ & $\begin{array}{l}\text { PRA_DER- } \\
\text { MASA_DER }\end{array}$ & $\begin{array}{l}\text { PRA_TDTA- } \\
\text { MASA_TDTA }\end{array}$ \\
\hline$z$ & $-4.198^{b}$ & $-3.163^{b}$ & $-2.555^{\mathrm{b}}$ & $-4.197^{b}$ & $-1.247^{b}$ & $-1.597^{\mathrm{b}}$ & $-1.825^{b}$ & $-1.088^{\circ}$ & $-.732^{\circ}$ \\
\hline Asymp. Sig. (2-tailed) & .000 & .002 & .011 & .000 & .212 & .110 & .068 & .277 & .464 \\
\hline
\end{tabular}

Gambar 4.1

Hasil Uji Wilcoxon Papan utama

Teknik pengambilan keputusan dalam uji Wilcoxon adalah dengan melihat nilai Asymp.sig. Jika Asymp.sig $>$ 0,05, maka tidak terdapat perbedaan signifikan antara kedua kelompok data. Jika asymp.sig $<\mathbf{0 , 0 5}$, maka terdapat perbedaan signifikan antara kedua kelompok data (Copper dan Schindler, 2014 : 613). Data masa dan pra pandemi covid-19 ROA, $N P M, G P M$, dan $R O E$ papan utama memiliki sig < 0,05 yang mengartikan bahwa terdapat perbedaan yang signifikan. Sedangkan sisanya tidak memiliki perbedaan yang signifikan.

\begin{tabular}{|c|c|c|c|c|c|c|c|c|c|}
\hline & $\begin{array}{l}\text { PRA_ROA- } \\
\text { MASA_ROA }\end{array}$ & $\begin{array}{l}\text { PRA_NPM - } \\
\text { MASA_NPM }\end{array}$ & $\begin{array}{l}\text { PRA_GPM - } \\
\text { MASA_GPM }\end{array}$ & $\begin{array}{l}\text { PRA_ROE- } \\
\text { MASA_ROE }\end{array}$ & $\begin{array}{l}\text { PRA_CURRE } \\
\text { NT- } \\
\text { MASA_CURR } \\
\text { ENT }\end{array}$ & $\begin{array}{l}\text { PRA_CASH - } \\
\text { MASA_CASH }\end{array}$ & $\begin{array}{l}\text { PRA_QUICK- } \\
\text { MASA_QUICK }\end{array}$ & $\begin{array}{l}\text { PRA_DER - } \\
\text { MASA_DER }\end{array}$ & $\begin{array}{l}\text { PRA_TDTA- } \\
\text { MASA_TDTA }\end{array}$ \\
\hline z & $-2.040^{b}$ & $-2.353^{\mathrm{b}}$ & $-2.667^{b}$ & $-2.275^{\mathrm{b}}$ & $-1.295^{b}$ & $-1.693^{b}$ & $-2.320^{\mathrm{b}}$ & $-2.004^{\circ}$ & $-2.163^{\circ}$ \\
\hline Asymp. Sig. (2-tailed) & .041 & .019 & .008 & .023 & .195 & .090 & .020 & .045 & .031 \\
\hline
\end{tabular}

Gambar 4.2

Hasil Uji Wilcoxon Papan pengembangan

Data masa dan pra pandemi covid-19 ROA, NPM, GPM, ROE, Quick ratio, DER, dan TDTA papan pengembangan memiliki sig $<0,05$ yang mengartikan bahwa terdapat perbedaan yang signifikan. Sedangkan sisanya tidak memiliki perbedaan yang signifikan. 


\section{DISKUSI}

Tabel 5.1

Kerangka Pembahasan Perusahaan Papan Utama

\begin{tabular}{|c|c|c|c|c|c|c|c|}
\hline \multicolumn{3}{|c|}{ Pra covid-19 } & \multicolumn{3}{|c|}{ Pasca Covid-19 } & Signifikansi & Kesimpulan \\
\hline \multicolumn{3}{|c|}{ Kinerja Keuangan } & \multicolumn{3}{|c|}{ Kinerja keuangan } & & \\
\hline 1 & ROA & $2,3 \%$ & 1 & ROA & $0,17 \%$ & $0,001<0,05$ & Negatif sebesar $2,14 \%$ dan Signifikan \\
\hline 2 & NPM & $23,54 \%$ & 2 & NPM & $-2,65 \%$ & $0,002<0,05$ & Negatif sebesar 26,19\% dan Signifikan \\
\hline 3 & GPM & $53,97 \%$ & 3 & GPM & $50,92 \%$ & $0,011<0,05$ & Negatif sebesar 3,05\% dan Signifikan \\
\hline 4 & ROE & $4,18 \%$ & 4 & ROE & $0,05 \%$ & $0,001<0,05$ & Negatif sebesar $4,12 \%$ dan Signifikan \\
\hline \multicolumn{3}{|c|}{ Kondisi Keuangan } & \multicolumn{3}{|c|}{ Kondisi Keuangan } & & \\
\hline 1 & Current Ratio & 3,36 & 1 & Current Ratio & 3,33 & $0,212>0,05$ & Negatif sebesar 0,03 dan Tidak signifikan \\
\hline 2 & Cash Ratio & 0,83 & 2 & Cash Ratio & 0,66 & $0,11>0,05$ & Negatif sebesar 0,17 dan Tidak signifikan \\
\hline 3 & Quick Ratio & 1,14 & 3 & Quick Ratio & 0,96 & $0,068>0,05$ & Negatif sebesar 0,18 dan Tidak signifikan \\
\hline 4 & DER & 0,94 & 4 & DER & 0,94 & $0,277>0,05$ & Perbedaan 0 dan Tidak signifikan \\
\hline 5 & TDTA & 0,4 & 5 & TDTA & 0,39 & $0,464>0,05$ & Negatif sebesar 0,01 dan Tidak signifikan \\
\hline
\end{tabular}

Setelah diuji dengan Wilcoxon dan melihat seberapa besar perbedaan yang ada, dapat disimpulkan bahwa pandemi covid-19 berpengaruh negatif dan signifikan terhadap ROE, ROA, $N P M$, dan GPM. Hal ini menunjukkan bahwa pandemi covid-19 memiliki pengaruh negatif dan signifikan terhadap kinerja keuangan perusahaan properti papan utama. Hipotesis mengenai pandemi covid-19 yang berpengaruh negatif dan signifikan terhadap ROE, ROA, $N P M$, dan GPM diterima. Pandemi covid-19 terbukti menurunkan kinerja keuangan perusahaan properti papan utama karena menurunnya daya beli masyarakat di saat pandemi. Masyarakat memfokuskan uangnya untuk memenuhi kebutuhan harian dan disimpan untuk berjaga - jaga dibandingkan dipakai untuk membeli rumah atau apartemen baru. Investor juga menahan diri mereka untuk melakukan pembelian investasi apapun karena melihat ekonomi yang belum pasti.

Setelah diuji dengan Wilcoxon dan melihat seberapa besar perbedaan yang ada, dapat disimpulkan bahwa pandemi covid-19 berpengaruh negatif dan tidak signifikan terhadap current ratio, cash ratio, dan quick ratio. Hal ini menunjukkan bahwa pandemi covid-19 memiliki pengaruh negatif dan tidak signifikan terhadap likuiditas perusahaan properti papan utama. Hipotesis mengenai pandemi covid-19 yang berpengaruh negatif dan tidak signifikan terhadap current ratio, cash ratio, dan quick ratio diterima. Walaupun terkena dampak pandemi covid-19, perusahaan properti papan utama ternyata masih dapat mengelola likuiditasnya dengan baik. Current ratio yang jauh di atas satu sebesar 3,33 dan quick ratio yang juga mendekati angka satu sebesar 0,96 mengindikasikan bahwa perusahaan properti papan utama tidak akan mengalami kesulitan dalam melanjutkan pengoperasian bisnisnya.

Setelah diuji dengan Wilcoxon dan melihat seberapa besar perbedaan yang ada, dapat disimpulkan bahwa pandemi covid-19 berpengaruh negatif dan tidak signifikan terhadap DER dan TDTA. Hal ini menunjukkan bahwa pandemi covid-19 memiliki pengaruh negatif dan tidak signifikan terhadap solvabilitas perusahaan properti papan utama. Hipotesis mengenai pandemi covid-19 yang berpengaruh positif dan tidak signifikan terhadap DER dan TDTA ditolak. Hipotesis dapat ditolak karena peningkatan aset dan ekuitas perusahaan papan utama lebih besar dibandingkan peningkatan hutang oleh pandemi covid-19. Hal ini 
mengindikasikan bahwa perusahaan properti papan utama sangat kuat walaupun menghadapi penurunan permintaan masa pandemi covid-19.

Kesimpulan mengenai pengaruh pandemi covid-19 terhadap kondisi keuangan papan utama tidak dapat disatukan karena hasil kesimpulan solvabilitas dan likuiditas saling bertolak belakang.

\section{Tabel 5.2}

Kerangka Pembahasan Perusahaan Papan Pengembangan

\begin{tabular}{|c|c|c|c|c|c|c|c|}
\hline \multicolumn{3}{|c|}{ PRA COVID 19} & \multicolumn{3}{|c|}{ PASCA COVID 19} & Signifikansi & Kesimpulan \\
\hline \multicolumn{3}{|c|}{ Kinerja Keuangan } & \multicolumn{3}{|c|}{ Kinerja keuangan } & & \\
\hline 1 & ROA & $0,6 \%$ & 1 & ROA & $-0,36 \%$ & $0,041<0,05$ & Negatif sebesar $0,95 \%$ dan Signifikan \\
\hline 2 & NPM & $1,74 \%$ & 2 & NPM & $-35,7 \%$ & $0,019<0,05$ & Negatif sebesar $37,44 \%$ dan Signifikan \\
\hline 3 & GPM & $48,7 \%$ & 3 & GPM & $38,08 \%$ & $0,008<0,05$ & Negatif sebesar $10,62 \%$ dan Signifikan \\
\hline 4 & ROE & $0,76 \%$ & 4 & ROE & $-1,38 \%$ & $0,023<0,05$ & Negatif sebesar 2,13\% dan Signifikan \\
\hline \multicolumn{3}{|c|}{ Kondisi Keuangan } & \multicolumn{3}{|c|}{ Kondisi Keuangan } & & \\
\hline 1 & Current Ratio & 2,87 & 1 & Current Ratio & 2,21 & $0,195>0,05$ & Negatif 0,66 dan Tidak signifikan \\
\hline 2 & Cash Ratio & 0,57 & 2 & Cash Ratio & 0,41 & $0,09>0,05$ & Negatif 0,16 dan Tidak signifikan \\
\hline 3 & Quick Ratio & 0,76 & 3 & Quick Ratio & 0,57 & $0,02<0,05$ & Negatif sebesar 0,2 dan Signifikan \\
\hline 4 & DER & 0,88 & 4 & DER & 1,08 & $0,045<0,05$ & Positif sebesar 0,2 dan Signifikan \\
\hline 5 & TDTA & 0,31 & 5 & TDTA & 0,35 & $0,031<0,05$ & Positif sebesar 0,04 dan Signifikan \\
\hline
\end{tabular}

Setelah diuji dengan Wilcoxon dan melihat seberapa besar perbedaan yang ada, dapat disimpulkan bahwa covid-19 berpengaruh negatif dan signifikan terhadap ROE, ROA, NPM, dan GPM. Hal ini menunjukkan bahwa pandemi covid-19 memiliki pengaruh negatif dan signifikan terhadap kinerja keuangan perusahaan properti papan pengembangan. Hipotesis mengenai covid-19 yang berpengaruh negatif dan signifikan terhadap ROE, ROA, $N P M$, dan GPM diterima. Sama seperti papan utama, covid-19 terbukti menurunkan kinerja keuangan perusahaan properti papan pengembangan karena menurunnya daya beli masyarakat di saat pandemi. Masyarakat memfokuskan uangnya untuk memenuhi kebutuhan harian dan disimpan untuk berjaga - jaga dibandingkan dipakai untuk membeli rumah atau apartemen baru. Investor juga menahan diri mereka untuk melakukan pembelian investasi apapun karena melihat ekonomi yang belum pasti.

Setelah diuji dengan Wilcoxon dan melihat seberapa besar perbedaan yang ada, dapat disimpulkan bahwa covid-19 berpengaruh negatif dan tidak signifikan terhadap current ratio dan cash ratio, tetapi berpengaruh negatif dan signifikan terhadap quick ratio. Hal ini menunjukkan bahwa pandemi covid-19 memiliki pengaruh negatif dan tidak signifikan terhadap likuiditas perusahaan properti papan pengembangan. Hipotesis mengenai covid19 yang berpengaruh negatif dan tidak signifikan terhadap current ratio dan cash ratio diterima, sedangkan quick ratio ditolak. Walaupun covid-19 tidak berpengaruh signifikan terhadap likuiditas perusahaan properti papan pengembangan, likuiditas perusahaan papan pengembangan sebelum ada covid-19 pun tidak dalam kondisi yang baik. Berbeda dengan perusahaan papan utama yang quick ratio sebelum covid-19 di atas satu, perusahaan papan pengembangan quick ratio-nya sudah di bawah satu sebesar 0,76 dan menjadi memburuk setelah covid-19 dengan quick ratio barunya sebesar 0,57. Hal ini mengindikasikan bahwa perusahaan properti papan pengembangan dapat mengalami kesulitan untuk melanjutkan operasional bisnisnya akibat kesulitan membayar hutang jangka pendek. 
Setelah diuji dengan Wilcoxon dan melihat seberapa besar perbedaan yang ada, dapat disimpulkan bahwa covid-19 berpengaruh positif dan signifikan terhadap DER dan TDTA. Hal ini menunjukkan bahwa pandemi covid-19 memiliki pengaruh positif dan signifikan terhadap solvabilitas perusahaan properti papan pengembangan. Hipotesis mengenai covid-19 yang berpengaruh positif dan tidak signifikan terhadap DER dan TDTA ditolak. Walaupun pengaruh covid-19 terhadap likuiditas tidak signifikan, ternyata pengaruh covid-19 terhadap solvabilitas signifikan. Hal ini menunjukkan bahwa perusahaan papan pengembangan mengambil banyak hutang jangka panjang sebagai sumber pendanaan operasionalnya. $D E R$ perusahaan papan pengembangan di atas satu menunjukkan bahwa perusahaan dapat mengalami kesulitan pembayaran hutang yang dapat mengakibatkan kesulitan keberlanjutan operasional.

Kesimpulan mengenai pengaruh covid-19 terhadap kondisi keuangan papan pengembangan tidak dapat disatukan karena hasil kesimpulan solvabilitas dan likuiditas saling bertolak belakang.

\section{PENUTUP}

Hasil penelitian menunjukkan bahwa pandemi covid-19 memiliki pengaruh signifikan dan negatif terhadap kinerja keuangan perusahaan properti papan utama dan papan pengembangan. Selain itu, pandemi covid-19 juga memiliki pengaruh negatif tetapi tidak signifikan terhadap likuiditas perusahaan properti papan utama dan papan pengembangan. Pandemi Covid-19 memiliki pengaruh negatif dan tidak signifikan terhadap solvabilitas papan utama, sedangkan terhadap papan pengembangan pandemi covid-19 memiliki pengaruh positif dan signifikan terhadap solvabilitasnya.

Walaupun kinerja perusahaan papan utama menurun signifikan oleh pandemi covid-19, perusahaan properti papan utama masih memiliki kondisi keuangan yang baik. Sedangkan, perusahaan properti papan pengembangan setelah kinerja keuangan menurun signifikan, kondisi keuangan perusahaan juga makin menurun dari awalnya yang juga sudah tidak baik.

Penelitian selanjutnya dapat mengambil rentang waktu penelitian yang lebih panjang yaitu melebihi dua tahun setelah pandemi covid-19 terjadi. Dengan begitu, informasi yang didapat menjadi lebih luas karena dapat melihat perkembangan sektor properti tahun setelah terdampak oleh pandemi covid-19.

\section{DAFTAR PUSTAKA}

Buvaneswar.R and Venkatesh.M. (2013). "A study on financial performance with special reference to sundaram hydraulics limited". Chennai International Journal of Advanced Research in Management and Social Sciences Vol. 2 No. 8, p 01-15

Chan, Toong Khuan; Abdul-Rashid Abdul-Aziz. (2017). "Financial performance and operating strategies of Malaysian property development companies during the global financial crisis". Journal of Financial Management of Property and Construction. Bingley Vol. 22, Iss. 2 : 174-191.

Cooper, D.R. dan Schindler, P.S. (2014). Business Research Methods. McGraw-Hill.

Ellyvon Pranita (2020) Diumumkan Awal Maret, Ahli: Virus Corona Masuk Indonesia dari Januari (retrieved from: https://www.kompas.com/sains/read/2020/05/11//03-01-2021)

Elok Sri Utami. (2017)." The effect of the crisis on financial performance of property sector in Indonesia". Investment Management and Financial Innovations, 14(1-1)248-253. DOI:10.21511/imfi.14(1-1).2017.11. 
Gitman, Lawrence J. 2003. Principles of Manajerial Finance International Edition 10th edition. Boston : Pearson Education.

Kamnikar, Judith A; Kamnikar, Edward G; Deal, Keren H. “Assessing a State's Financial Condition." The Journal of Government Financial Management; Alexandria Vol. 55, Iss. 3, (Fall 2006): 30-36.

Lai, Hui Ying; Abdul Rashid Abdul Aziz; Chan, Toong Khuan. (2014). " Effect of the global financial crisis on the financial performance of public listed construction companies in Malaysia ". Journal of Financial Management of Property and Construction; Bingley Vol. 19, Iss. 3, (2014): 246-263. DOI:10.1108/JFMPC-02-2014-0002.

Pipit Ika Ramadhani (2020) HEADLINE: Nasib Dunia Usaha di Tengah Pandemi Corona,(Retrieved from: https://www.liputan6.com/bisnis/read/4228742/07/01/2021)

Richard L. Daft and Dorothy Marcic, Understanding Management (Mason, Ohio: SouthWestern Cengage Learning, 2009) p.50. 